Kepemimpinan Kepala Sekolah Dasar Negeri - 205

Muhammad Nurdin, Husaini Usman

\title{
KEPEMIMPINAN KEPALA SEKOLAH DASAR NEGERI 1 TALIWAN KABUPATEN SUMBAWA BARAT
}

\author{
Muhammad Nurdin, Husaini Usman \\ SD Negeri 2 Mura Brang Ene Sumbawa Barat, Universitas Negeri Yogyakarta \\ M_nurdin87@yahoo.com
}

\begin{abstract}
Abstrak
Penelitian ini bertujuan untuk menegtahui kepemimpinan Kepala Sekolah sebagai leader, bentuk dukungan dari followers, dan situasi sekolah yang kondusif bagi kepemimpinan Kepala Sekolah di Sekolah Dasar Negeri 1 Taliwang. Penelitian ini dilaksanakan di SDN 1 Taliwang Kabupaten Sumbawa Barat, menggunakan jenis penelitian kualitatif dengan pendekatan studi kasus.Subjek utamanya adalah Kepala Sekolah, satu guru putra, satu guru putri, unsur komite sekolah, satu staf tata usaha sekolah, dan security sekolah. Data dikumpulkan melalui wawancara, observasi, dan dokumentasi.Pengamatan dilakukan secara terus menerus tentang aktivitas yang berlangsung di sekolah.Di dalam observasi ini, juga dilakukan pemotretan terhadap objek-objek yang mendukung kepemimpinan Kepala Sekolah. Data yang diperoleh dari Kepala Sekolah, dikroscek kembali terhadap pernyataan para subjek lainnya.Pengumpulan data dilakukan secara berulang-ulang sampai data tersebut jenuh. Data yang dianalisis menggunakan model Interaktif Milles dan Huberman yaitu reduksi data, display data, dan penarikan kesimpulan. Hasil penelitian ini adalah sebagai berikut: 1). Kepemimpinan Kepala Sekolah sebagai leader yang diwujudkan dengan memberikan keteladanan, motivasi, dan mendukung warga sekolah untuk meningkatkan kompetensinya. 2). Bentuk dukungan dari followers bagi kepemimpinan Kepala Sekolah berupa loyalitasnya untuk menjalankan tugas dan arahan yang diberikan oleh Kepala Sekolah. 3). Bentuk dukungan dari situasi sekolah berupa lingkungan yang nyaman dan kondusif untuk mendukung keberhasiln proses pembelajaran.
\end{abstract}

Kata kunci: kepemimpinan, kepala sekolah, kepemimpinan kepala sekolah, sekolah dasar

\section{THE HEADMASTER'S LEADERSHIP ATPUBLIC ELEMENTARY SCHOOL 1 TALIWANG IN SUMBAWA BARAT REGENCY}

\begin{abstract}
The objective of this research was to know the Headmaster's leadership as a leader, the supports from the followers, and the conducive situationat Sekolah Dasar Negeri(hereafter SD N) 1 Taliwang. This research was conducted at SDN 1 Taliwang in Sumbawa Barat Regency using qualitative research with case-study approach. The main subjects were the Headmaster, a male teacher, a female teacher, the school committee, the staff of administration, and the security guards. The data were collected through the interview, observations and documentation. The observations were conducted continuously while the teaching-learning activities at the school.There were some suitable pictures taken for this research during the observation processes. The data from the Headmaster were crosschecked with the statements from the other subjects. The data crosschecking were proceed repeatedly to get them saturated. The data were analyzed by using the interactive model of Milles and Huberman, namely datareduction, data display, and conclusion drawing. The results of this research are: 1) As a leader, the Headmaster's leadership was manifested through modelling, motivating, and supporting all school elements in order to improve their competence 2) The supports from the followers for the leader could be seen from their loyalty to do their jobs and to follow the Headmaster's instruction 3) The supports from the school situation could be seen from comfortable and conducive environment which reinforced the teaching-learning success.
\end{abstract}

Keywords: leadership, headmaster, headmaster's leadership, and elementary school 


\section{Pendahuluan}

Keberadaan pemimpin dalam sebuah organisasi mutlak diperlukan, baik organisasi formal maupun nonformal. Keformalan organisasi atau lembaga sekolah akan berpengaruh terhadap kompleksitas hubungan antara pemimpin dengan bawahannya dalam organisasi bersangkutan. Sekolah merupakan wadah yang tepat untuk memciptakan kader-kader calon pemimpin bangsa yang sanggup mengatasi permasalahan-permasalahan sosial yang terdapat di dalam lembaga pendidikan khususnya menuju ke arah perbaikan yang lebih baik.

Sekolah juga menghindari pembentukkan moral yang rendah (low morale) dan anti sosial antara kelompok yang miskin (have-not) dengan kelompok kaya (haves). Melalui pendidikan ini juga dapat membentuk sikap dan nilai-nilai moral sosial yang menjadi panutan bagi seluruh masyarakat, dalam pergaulan sehari-hari. Dengan kata lain bahwa pendidikan merupakan kekuatan (power) bagi suatu negara baik riil maupun tertulis, dan pendidikan juga mengarah pada pembentukan keterampilan dasar.

Kepala Sekolah yang memimpin suatu sekolah tersebut diupayakan pengangkatannnya melalui pertimbangan-pertimbangan yang syarat dengan kompetensi yang dibutuhkan untuk memimpin suatu sekolah itu. Sekolah sebagai salah satu organisasi, maka harus dipimpin oleh seorang dengan bentuk kepemimpinan formal (formal leadership). Kepemimpinan formal terjadi apabila di lingkungan organisasi jabatan otoritas formal dalam organisasi tersebut diisi oleh orang-orang yang ditunjuk atau dipilih melalui proses seleksi (Wahjosumidjo (2011: 84).

Keberhasilan suatu sekolah banyak faktor yang menentukannya. Faktor yang utama tentang manajemen pengelolaan oleh pinpinan sekolah tersebut. Manajerial sekolah yang efektif itu membutuhkan orang yang kompeten dalam bidang ini. Untuk menjadi sekolah yang efektif memerlukan Kepala Sekolah yang memiliki visi dan misi yang efektif pula. Komponen kepemimpinan ini sangat memengaruhi aspek-aspek yang lainnya dalam mewujudkan tujuan yang direncanakan di suatu sekolah. Kepala Sekolah menjalankan kepemimpinan manajerial di sekolah harus berinteraksi dengan baik, dengan sejumlah personel dalam sistem tersebut.

Pelaksanaan fungsi Kepala Sekolah baik sebagai leader maupun sebagai motivator tidak dapat dipisahkan satu sama lain dan saling menyatu dalam pribadi seorang Kepala Sekolah yang profesional. Istilah profesional yang disandang oleh Kepala Sekolah itu menurut Kusnandar (Euis Karwati \& Priansa D.J, 2013: 113) menyatakan: "Bahwa profesionalisme merupakan istilah yang mengacu pada sikap mental dalam bentuk komitmen dari para anggota suatu profesi untuk senantiasa mewujudkan dan meningkatkan kualitas profesionalnya". Berdasarkan Permendiknas Nomor 28 Tahun 2010 pasal 2 ayat (2) bahwa syarat untuk seleksi administrasi calon Kepala Sekolah minimal memegang gelar Sarjana Pendidikan (S1), usia minimal 56 tahun padat pengalaman minimal 5 tahun sebagai pendidik. Sementara untuk seleksi akademik, pada pasal 5 ayat (3) dinyatakan bahwa penilaian dilakukan melalui potensi kepemimpinan.Manajerial sekolah yang efektif itu membutuhkan orang yang kompeten dalam bidang ini. Penanganan dan pengelolaan dari sisi administrasi dengan baik dan profesiaonal mencerminkan keberhasilan sekolah yang efektif.

Menjadi sekolah yang efektif memerlukan Kepala Sekolah yang memiliki visi dan misi yang efektif pula. Paparan ini sebagaimana pernyataan yang berbunyi "Effective schools are led by effective principals", sekolah yang efektif itu apabila dipimpin oleh kepala sekolah yang efektif pula (Sorenson \& Goldsmith, 2009: 58). Kegagalan sekolah menciptakan kondisi pembelajaran yang efektif dan efisien akan berdampak pada mutu dan masa depan peserta didik. Semua komunitas sekolah memerlukan bimbingan dan pembinaan dari Kepala Sekolah dalam upaya me- 
wujudkan proses belajar yang efektif (Sudarwan Danim \& Suparno, 2009: 13).

Para pemimpin pendidikan harus memiliki komitmen, dan bertanggung jawab untuk melakukan pemberdayaan kepada semua guru di sekolah yang di pimpinnya. Pemimpin harus melakukan pencerahan untuk mendorong para bawahan dan stafnya agar mau berkeja dengan sebaik-baiknya untuk mencapai tujuan yang telah digariskan itu adalah merupakan suatu hal yang harus dilakukan oleh seorang pemimpin pendidikan di lembaganya.Dalam rangka pemberdayaan guru sebagai upaya pencapaian tujuan pendidikan, maka Kepala Sekolah harus dapat memberikan kepercayaan kepada guru untuk mengadakan berbagai kreativitas, inovasi dalam mejalankan tugas sesuai dengan fungsinya, sebagai salah satu unsur keberhasilan program sekolah.

Berdasarkan uraian di atas, kenyataan di lapangan masih banyak kepemimpinan Kepala Sekolah yang belum relevan dengan konsep manajemen Kepala Sekolah yang efektif. Kepala Sekolah masih mengalami kesulitan mengelola dan memimpin sekolahnya. Namun, salah satu sekolah di Kecamatan Taliwang yaitu Sekolah Dasar Negeri 1 Taliwang Kabupaten Sumbawa Barat, setiap tahunnya selalu menunjukkan prestasi terbaik dalam menamatkan siswanya dengan hasil yang sangat memuaskan banyak pihak. Prestasi sekolah ini selalu berada di papan atas perolehan hasil ujian nasional setiap tahunnya. SDN 1 Taliwang ini selalu menghasilkan para siswa yang unggul di bidang akademik dalam kompetisisi yang diselenggarakan oleh dinas pendidikan. Di samping itu SDN 1 Taliwang juga sering menghasilkan siswa yang unggul dalam kompetisi pengembangan bakat dan kreativitas anak yang di selenggarakan oleh bidang pengembangan bakat dan minat Dinas Pendidikan dan Kebudayaan Kabupaten Sumbawa Barat.

Berbagai masalah yang telah berhasil diidentifikasi tersebut, mengingat keterbatasan waktu, tenaga, dan biaya, maka masalah-masalah yang teridentifikasi di atas dibatasi tentang "Kepemimpinan Kepala Sekolah Dasar sebagai leader" di Sekolah Dasar Negeri 1 Taliwang Kabupaten Sumbawa Barat.

Berdasarkan batasan masalah di atas, maka disusun rumusan masalah dalam penelitian ini adalah:

Bagaimana kepemimpinan Kepala sekolah sebagai leader; Bagaimana bentuk dukungan followers; dan Bagaimana dukungan situasi sekolah bagi kepemimpinan Kepala Sekolah Dasar Negeri 1 Taliwang Kabupaten Sumbawa Barat?

Bertitik tolak dari rumusan masalah yang dikemukakan di atas, maka tujuan penelitian adalah untuk mengetahui:

Kepala Sekolah sebagai leader; dukungan dari followersserta seluruh stakeholders lainnya; dan dukungan situaisi sekolah yang kondusif bagi kepemimpinan Kepala Sekolah Dasar Negeri 1 Taliwang Kabupaten Sumbawa Barat.

Dari semua fungsi dan manfaat seorang pemimpin dalam dunia pendidikan itu, jika dimiliki oleh seorang pemimpin pendidikan, maka dapat dipastikan bahwa sekolah tersebut dapat berjalan dengan lancar, dan sukses untuk mencapai tujuan pendidikan. Hal ini sesuai dengan pendapat Fink \& Brayman(Cunningham, 2009: 12) menyatakan bahwa: "Seiring waktu, pengalaman baru dan tantangan baru membantu mengembangkan pemahaman tentang dinamika pendidikan, diperlukan tanggung jawab yang signifikan dari setiap pemimpin pendidikan, yang berkaitan dengan ini Kepala Sekolah merupakan jabatan yang sentral dalam mewujudkan harapan yang diimpaikan itu".

Kepemimpinan pendidikan merupakan kepemimpinan Kepala Sekolah sebagai leader terhadap uapaya peningkatan mutu pendidikan di sekolah. Penentuan bahwa sekolah atau institusi itu bermutu atau tidaknya adalah kepemimpinan pendidikan sebagaimana dikemukakan oleh Petter \& Austin (Sallis, 2011: 170) menyatakan bahwa: Gaya kepemimpinan tertentu dan tepat sasaran dapat mengantarkan institusi pada revolusi mutu, sebuah gaya yang disingkat MBWA atau 
manajement by walking about (manajemen dengan melaksanakan)".

Kepemimpinan pendidikan di sekolah sangat diperlukan inovasi-inovasi dan kreativitas yang bersumber dari dalam diri pemimpin itu, dan program yang harus dilakukan oleh jajaran pimpinan pendidikan di atasnya untuk memperkaya pengetahuan dan kemampuan para pimpinan pendidikan di tingkat sekolah. Pemberdayaan kompetensi kemampuan Kepala Sekolah di seluruh aspek ilmu pengetahuan itu menjadi modal dasar yang harus dimiliki oleh Kepala Sekolah. Pemerkaya kemampuan Kepala Sekolah ini menjadi acuan bagi Kepala Sekolah untuk bersaing dalam promosi tugas tambahan selanjutnya.

Kepemimpian pendidikan merupakan unsur yang kerap menjadi penentu keberhasilan di sekolah. Adapun definisi kepemimpinan Kepala Sekolah menurut Yukl (1994: 2-3) menyatakan antara lain:

a. Kepmimpinan adalah perilaku seorang individu yang memimpin aktivitasaktivitas suatu kelompok ke suatu tujuan yang ingin dicapai bersama (shared goal).

b. Kepemimpinan adakah pengaruh antar pribadi yang dijalankan dalam suatu situasi tertentu, serta diarahkan melalui proses, komunikasi ke arah pencapaian satu atau beberapa tujuan tertentu.

c. Kepemimpinan adalah pembentukan awal serta pemeliharaan struktur dalam harapan dan interaksi.

d. Kepemimpinan adalah peningkatan pengaruh sedikit demi sedikit, pada dan berada di atas kepatuhan mekanis terhadap pengarahan-pengarahan rutin organisasi.

e. Kepemimpinan adalah proses mempengaruhi aktivitas-aktivitas sebuah kelompok yang diorganisasi ke arah pencapaian tujuan.

f. Kepemimpinan adalah sebuah proses memberikan arti (pengarahan yang berarti) terhadap usaha kolektif, dan yang mengakibatkan kesediaan untuk melakukan usaha yang diinginkan untuk mencapai sasaran.

g. Para pemimpin adalah mereka yang secara konsisten memberikan kontribusi yang efektif terhadap orde sosial, serta yang diharapkan dan dipersepsikan melakukannya.

Pendidikan di tingkat sekolah diupayakan memiliki dewan sekolah yang dapat membantu atau memonitor jalannya proses pendidikan di sekolah itu, tentang kelebihan dan kekurangan yang dimiliki oleh sekolah. Dewan sekolah itu harus memiliki kemampuan yang tepat dalam membantu sekolah di lingkungannya. Dewandewan sekolah itu menurut Cunningham (2009: 12) harus memenuhi beberapa persyaratan yang mendasar untuk membantu sekolahnya, antara lain.

a. Memiliki pengalaman kepemimpinan sebagai pengawas atau pernah mengsistemisasi pengawas sistem sekolah, dan pengalaman mengajar yang sukses sebagai guru dan begitu juga sebagai Kepala Sekolah.

b. Berperilaku yang standar dan beretika yang terpuji, serta menjadi panutan dalam berperan sebagai pelaku pendidikan di tingkat sekolah.

c. Memiliki pengalaman, pemahaman, dan kemampuan yang berkaitan dengan anggaran dalam proses penganggaran dana sekolah.

d. Menguasai manajemen sekolah seperti manajemen kurikulum, serta pengetahuan-pengatahuan khusus dalam instruksi dimensi proses ppembelajran untuk meningkatkan prestasi siswa.

e. Komitmen untuk membina hubungan kerjasama dengan personil, dewan sekolah, dan masyarakat.

f. Berkomunikasi yang baik dan mempunyai kemampuan interpersonal, serta pengalaman kerja yang sukses dalam masyarakat multicultural.

Pengelolaan seluruh program atau perencanaan pendidikan di sekolah sangat memerlukan figur yang dapat menggerakkan semua pihak, dalam rangka mengefektifkan seluruh fungsinya dan 
tugasnya masing-masing. Apabila kita membahas tentang sosok figur pimpinan pendidikan di suatu lembaga pendidikan, pimpinan yang akan memimpin sekolah itu harus memiliki kompetensi-kompetensi yang cukup dalam melakukan perannya untuk memimpin suatu sekolah.Pemimpin yang menjadi harapan masyarakat sekolah adalah pemimpin yang mempunyai kompetensi kepemimpinan yang dapat menggerakkan seluruh sumber daya dalam organisasinya. Kepala Sekolah dalam memimpin atau menerapkan kepemimpinannya selalu berusaha memperoleh hasil maksimal dalam kepemimpinannya itu. Menurut Crawford \& Brooke (2013: 2) menyatakan: "Kepemimpinan yang efektif dimulai dengan pengetahuan luas tentang lingkungan instruksional: kebutuhan individu siswa, kekuatan dan kelemahan dari anggota staf, aspek program pembelajaran, data siswa, dan jadwal. Ini adalahcara di manapara pemimpin sekolah untuk mengetahui ide-ide pikiran para guru serta memberdayakannya dalam meningkatkan keberhasilan kinerjanya bahwa mereka meletakkan dasar bagi kepemimpinan sekolah yang efektif".

Kepemimpinan sekolah adalah kapasitas kepemimpinan sekolah dalam memahami dan mengembangkan dirinya, menciptakan dan mengartikulasikan (visi, misi, tujuan, sasaran, dan strategi sekolah), meyakini bahwa sekolah adalah tempat belajar, mempengaruhi, memberdayakan, memobilisasi, membimbing, membentuk kultur, memberi contoh, menjaga integritas, berani mengambil resiko sebagai pionir dalam pembaruan (kemauan untuk mengetahui yang belum diketahui, melakukan inovasi dan eksperimentasi agar menemukan cara-cara baru untuk mengerjakan sesuatu).

Menurut Gibson menyebutkan fungsi manajemen dengan singkatan POLC, yaitu Planning, Organizing, Leading, and Controlling. Sehubungan dengan singkatan di atas, maka pemimpin pendidikan bermanfaat dalam dunia pendidikan dan berfungsi anatara lain sebagai personnal, educator, manager, administrator, supervisor, social, leader, entrepreneur, and climator (PEMASSLEC)(Husaini Usman, 2011: 277).

Menurut Lev Vigotsky dalam kaitannnya sebagai guru ini ia menyatakan sebagai berikut: "Bahwa ada cela antara kemampuan murid memecahkan masalah secara independen dengan kemampuannnya memecahkan masalah pada saat ia didampingi orang yang lebih tahu. Hal inilah salah satu teknik yang dapat digunakan Kepala Sekolah untuk menginspiratifkan para guru (Neila Ramdhani, 2012, 14)". Menjalankan fungsi kepengawasan ini Kepala Sekolah harus dapat melakukan supervisi yang tepat dan dapat memberikan bantuan kepada guru untuk mengatasi kesulitan dalam mnjalankan tugas. Hal ini lebih ditegaskan Sergiovani (Lantip Diat Prasojo, 2011, 84) menegaskan bahwa: "Refleksi praktis penilaian kinerja guru dalam supervisi akademik adalah melihat kondisi nyata kinerja guru untuk menjawab pertanyaan misalnya: Apa yang sebenarnya terjadi di dalam kelas? Apa yang sebenarnya dilakukan oleh guru dan peserta didik di dalam kelas? Aktivitasativitas mana dari keseluruhan aktivitas di dalam kelas itu yang bermakna bagi guru dan peserta didik? Apa yang telah dilakukan oleh guru dalam mencapai tujuan akademik? Apakelebihan dan kekurangan guru dan bagaimana caran mengembangkannya?

Menurut Hersey \& Blanchard (Husaini Usman, 2011: 321) adalah sebagai berikut. Gaya mendikte (Telling), Gaya ini diterapkan jika anak buah dalam tingkat kematangan rendah, dan memerlukan petunjuk serta pengawasan yang jelas; Gaya Menjual (Selling), gaya ini diterapkan apabila kondisi bawahan dalam taraf rendah sampai moderat mereka telah memiliki kemauan untuk melakukan juga, tetapi belum didukung oleh kemampuan yang memadai; Gaya Melibatkan Diri (Participating), gaya ini diterapkan apabila tingkat kematangan bawahan berada pada taraf kematangan moderat sampai tinggi; dan gaya Mndelegasikan (delegating), gaya ini diterapkan jika kemampuan dan kemauan bawahan telah tinggi. 
Model kepemimpinan tansformasional (tarnsformational) menurut Bush menyatakan (Husaini Usman, 2011: 374) menyatakan: "Bahwa model kepemimpinan transformasional adalah model yang konprehensif yang menggunakan pendekatan normatif. Model ini berbuat sewenang-wenang karena kepemimpinan yang kuat, berani berkorban sebagai pahlawan, karismatik, dan konsisten dengan teman sejawat dalam berbagi nilai-nilai dan kepentingan-kepentingan umum.

Faktor-faktor yang mempengaruhi keefektifan kepemimpinan Kepala Sekolah dalam hal ini dengan menganut teori kontingensi. Menurut teori ini keefektifan kepemimpinan Kepala Sekolah ditentukan oleh tiga variabel, yaitu: "gaya pemimpin, keadaan pengikut (followers), serta situasi (situation) dimana pun kepemimpinan itu diimplementasikan" (Wuradji, 2009: 26).

Nilai-nilai inti yang harus diterapkan menurut Blanchart (Husaini Usman, 2011: 359) adalah:

1. Etika-bekerja efektif;

2. Hubungan mengembangankan kepercayaan dan rasa hormat;

3. Sukses-menjalankan organisasi dengan sebaik-baiknya dan menguntungkan;

4. Pembelajaran- selalu meningkatkan kualitas diri dan rasa ingin tahu.

Esensi kepemimpinan adalah kepengikutan (followership), kemauan orang lain atau bawahan untuk mengikuti keinginan pemimpin, itulah yang menyebabkan seorang menjadi pemimpin menurut Yukl (1994: 5) bahwa: "Ledership is defined broadly as influence process affecting the interpretation of event for follower, the choice of objectives for the group or organization, the organization of work activities to accomplish the objectives, the maintenance of cooperative relationships and teamwork, and the enlistment of support and cooperation from people outside the group or organization".

Kepemimpinan dirumuskan sebagai proses mempengaruhi orang-orang dalam hal: penginterpretasian peristiwa (aspirasi) pengikutnya, pemilihan tujuantujuan organisasi, pengorganisasian kegiatan kerja untu mencapai tujuan, dan penge- rahan dukungan serta kerja sama dari orang-orang di luar kelompok atau organisasi.

Tugas Kepala Sekolah menurut Wahjosumidjo antara lain (Euis Karwati \& Donni Juni Priansa, 2013: 129): antara lain: 1) Saluran komunikasi, 2) Bertanggung jawab dan mempertanggungjawabkan, 3) Kemampuan menghadapi persoalan, 4) Berpikir analitik dan konsepsional, 5) Sebagai mediator atau juru penengah, 6) Sebagai politisi, 7) Sebagai diplomat, dan 8) Pengambil keputusan sulit.

Kepala Sekolah di dalam memimpin suatu sekolah harus dapat memotivasi atau meningkatkan kinerja bawahannnya dengan cara yang tidak menimbulkan rasa senang dari para bawahan sesuai dengan yang diungkapkan Lutan (Agustin, 2011, 19) menyatakan: "Bahwa seorang yang memiliki kadar motivasi berprestasi yang tinggi memperlihatkan kecenderungan pendekatan yang positif dalam menjalankan tugasnya dan selalu berorientasi pada prestasi".

Menurut Sudarwan Danim dan Suparno (2009: 28) menyatakan bahwa ada beberapa tugas dan tanggung jawab Kepala Sekolah dalam mengelolah pendidikan meliputi: 1) Mengelola seluruh sumber daya manusia, fasilitas dan dana, 2) Membuat keputusan, 3) Menjadi teladan, 4) Menyelenggarakan tugas-tugas administrasi, 5) Melakukan inovasi, 6) Melaksanakan tugas sebagai supervisor atau penyelia, 7) Melaksanakan tugas sebagai pencipta kondisi yang kondusif untuk belajar, dan 8) Melaksanakan tugas selaku pembimbing guru, staf administrasi, dan siswa.

Menurut berpendapat seperti James Keefe (Stolp \& Smith, 1995: 16) menyatakan bahwa "pembentukan lingkungan yang beriklim kondusif untuk mendukung keberhasilan seluruh program perencanaan sekolah oleh Kepala Sekolah merupakan hal yang mutlak". Lingkungan yang kondusif itu sangat dibutuhkan oleh seluruh komponen pendidikan dalam proses pembelajarannya. Seluruh nilai, norma, adat kebiasaan yang berkembang di suatu daerah sekitar sekolah akan terintegrasi 
dengan baik dan sebagai modal dasar bagi semua guru di dalam mengaplikasikan perencanaan materi pembelajarannnya.

Berdasarkan permasalahan-permasalahan kepemimpinan yang dilaksanakan, maka pertanyaan yang akan dijawab dalam penelitian ini adalah:

1. Bagaimana Kepala Sekolah sebagai leader dalam rangka menigkatkan kompetensi tenaga pendidik di sekolah yang ia pimpin?

2. Upaya-upaya Kepala sekolah untuk menjalankan visi, misi, tujuan, dan sasaran di sekolah binaannya sehubungan dengan fungsinya sebagai leader?

3. Bagaimana bentuk dukungan followers terhadap implementasi program sekolah sebagai feedback dari kegiatan pemberdayaan yang dilakukan Kepala Sekolah kepada guru, dan karyawan sekolah untuk meningkatkan kompetensinya dalam mendukung keefektifan kepemimpinannya?

4. Bagaimana prestasi yang diperoleh para siswa, guru ataupun karyawan dan bagaimana model apresiasi yang dilakukan Kepala Sekolah kepada mereka yang berprestasi dalam mengharumkan nama baik sekolah?

5. Bagaimana bentuk kegiatan yang dilakukan kepala sekolah dalam upaya menciptakan situasi sekolah yang kondusif, dan harmonis sehingga dapat mendukung pencapaian tujuan pendidikan di sekolah?

6. Apa saja hal-hal yang dianggap positif oleh Kepala Sekolah dalam rangka mengkolaborasikan sekolah dengan lingkungan untuk mendukung terbentuknya kebudayaan sekolah yang bermartabat?

\section{Metode Penelitian}

Jenis Penelitian

Penelitian ini menggunakan penelitian kualitatif dengan pendekatan studi kasus. Penelitian ini mengandung prinsip bahwa penelitian berusaha memperoleh kebenaran sesuatu dengan cara mengungkap fakta atau gejala yang terjadi di lapangan.Penelitian kualitatif ini harus bersifat "perspetitive emic" artinya memperoleh data bukan "sebagai mana seharusnya", bukan berdasarkan apa yang dipikirkan oleh peneliti, tetapi berdasarkan sebagaimana adanya yang terjadi di lapangan, yang dialami, dirasakan, dan dipikirkan oleh partisipan atau sumber data.

Pendekatan ini digunakan karena tujuan penelitian yang hendak dicapai adalah menggambarkan peta dan kegiatankegiatan yang dilakukan Kepala Sekolah sehubungan dengan proses kepemimpinannya di Sekolah Dasar Negeri 1 Taliwang Kabupaten Sumbawa Barat.

\section{Waktu dan Tempat Penelitian}

Penelitian ini dilakukan di Sekolah Dasar Negeri 1 Taliwang Kabupaten Sumbawa Barat dengan pertimbangan adalah sebagai berikut: 1) Sekolah Dasar Negeri 1 Taliwang merupakan Sekolah Dasar Gugus Inti oleh UPT Dinas Pendidikan dan Kebudayaan No. 422/123/UPTD/2011 tentang penetapan Gugus SD pada lingkup pelaksana teknis dinas Dikpora Kecamatan Taliwang tanggal 28 November 2011, 2) SDN I Taliwang ini merupakan sekolah yang banyak menghasilkan siswa-siswa yang berprestasi. Siswa-siswa yang berprestasi dalam dua tahun terakhir menunjukkan bahwa dari tingkat kecamatan sampai dengan tingkat nasional.

Subjek penelitian

Subyek penelitian adalah Kepala Sekolah sebagai key informan. Subyek yang berikutnya adalah satu guru laki-laki, satu guru perempuan, salah satu unsur komite sekolah, salah satu staf karyawan sekolah, dan security sekolah.

\section{Prosedur Penelitian}

Dalam rangka mendapatkan data yang valid atau benar-benar nyata dan akurat, peneliti melewati langkah-langkah pengambilan data yang teratur dan sistematis. Data yang terkumpul untuk sebuah penelitian kualitatif itu merupakan data- 
data yang diperoleh dari langkah-langkah yang dituntun oleh teori research yang diakui keabsahannya secara mendunia.

Tahapan pengumpulan data dalam penelitian itu, peneliti ini sesuai dengan langkah-langkah menurut McMillan (2013: 276) mengawalinya dari pengamatan secara mendetail (Gather extensive detailed data), kemudian teks data-data tersebut dibaca atau dicatat (Close reading of text or notes), lalu tahapan berikutnya data-data itu diberi kode dan memverifikasinya (Code and verify data), setelah itu peneliti melakukan pengkategorian dari data yang telah dibubuhi kode tersebut (Create categories from codes), langkah selanjutnya peneliti mereduksi data-data yang telah dikodekan itu untuk mengambil atau melihat datadata yang cocok dengan tujuan penelitiannya serta menyisihkan data yang tak terpakai (Reduce categories to eliminate redundancy), dan pada akhirnya peneliti dapat mengambil kesimpulan terhadap hasil penelitiannya untuk menetapkan modelnya dan sebagainya (Conclusion, model, framework, or structures).

Data, Instrumen, dan Teknik Pengumpulan Data

Data yang diungkap melalui teknik observsi dalam penelitian ini adalah tentang gejala yang tampak pada kepemimpinan kepala sekolah, cara-cara memotivasi para guru untuk meningkatkan kinerja dalam upaya pencapaian tujuan pendidikan di sekolah, bentuk apresiasi terhadap para guru, karyawan, dan siswa dalam rangkah meemberikan reward yang dapat membangkitkan semangat semua komponen pendidikan untuk kemajuan bersama.

Penelitian ini menggunakan beberapa pertanyaan sebagaimana daftar pertanyaan wawancara antara Lain: Bagaimana usaha yang bapak lakukan sehubungan dengan peran bapak sebagai leader, Bagaimana upaya yang bapak lakukan dalam rangka mengefektifkan peran bapak sebagai administrator sekolah, Bagaimana bentuk kegiatan yang bapak lakukan untuk menjalankan visi, dan misi, Apakah ada hambatan-hambatan dalam menerapkan visi dan misi sekolah, Bagaimana bentuk dukungan dari followers dan pemberdayaan yang Kepala Sekolah, Bagaimana teknik atau metode yang Kepala Sekolah gunakan untuk memberikan motivasi kepada bawahan, Apa saja bentuk penghargaan yang diberikan kepada guru atau karyawan berprestasi dalam rangka mengharumkan nama baik sekolah ini pak, Bagaimana bentuk apresiasi yang bapak berikan kepada guru dalam kegiatan-kegiatan lain, juga dalam rangka mengangkat nama baik sekolah ini pak, Bagaimana bentuk kegiatan yang bapak dilakukan dalam upaya menciptakan situasi sekolah yang harmonis pak, Apakah pembentukan sekolah yang harmonis dan kondusif ini bapak menemui beberapa hambatan dalam pelaksanaannya,Bagaimana upaya yang bapak lakukan untuk mengkolaborasikan nilai-nilai budaya sekolah dengan lingkungan sekitar sekolah ini pak, dan Apa saja hal positif dari lingkungan, yang dapat diterapkan di sekolah ini untuk membentuk siswa yang memiliki kepribadian yang bermartabat pak?

Proses pengumpulan data dilakukan dengan beberapa tahap. Tahap perta$m a$, yaitu orientasi dengan cara peneliti mengumpulkan data secara umum dan luas tentang hal yang penting, menonjol dan berguna untuk diteliti lebih jauh. Tahap kedua, merupakan pengumpulan data dengan cara langsung dari sumber data yang dijadikan sumber informasi. Tahap ketiga, peneliti melakukan penelitian terfokus yaitu pada kepemimpinan Kepala Sekolah.

Data yang diungkap melalui teknik observsi dalam penelitian ini adalah tentang gejala yang tampak pada kepemimpinan kepala sekolah, cara-cara memotivasi para guru untuk meningkatkan kinerja dalam upaya pencapaian tujuan pendidikan di sekolah, bentuk apresiasi terhadap para guru, karyawan, dan siswa dalam rangkah meemberikan reward yang dapat membangkitkan semangat semua komponen pendidikan untuk kemajuan bersama. 
Wawancara digunakan untuk mempertajam dan mengembangkan informasi berkaitan dengan data yang diperoleh dari observasi tentang kepemimpinan Kepala Sekolah dalam memacu semangat kerja para guru, karyawan dan siswa.

Dokumentasi yang diperlukan peneliti dalam penelitian ini adalah meliputi keadaan demografi Sekolah Dasar Negeri 1 Taliwang Kabupaten Sumbawa Barat. Selain itu pula dokumen program kegiatan kepala sekolah dalam rangka memberikan motivasi atau dorongan kepada guru, karyawan, dan siswa untuk meningkatkan mutu pendidikan di sekolah bersangkutan.

\section{Teknik Analisis Data}

Penyajian data agar lebih bermakna dan mudah dipahami, maka langkah analisis data yang digunakan dalam penelitian ini adalah analisis interactive model dari Miles dan Huberman (1994: 23) yang membagi kegiatan analisis menjadi beberapa bagian yaitu: pengumpulan data, pengelompokkan menurut variabel, reduksi data, penyajian data, memisahkan outlier data, dan penarikan kesimpulan atau verikasi data.

\section{Hasil Penelitian dan Pembahasan}

Kepala Sekolah sebagai Leader

Kepala Sekolah Dasar Negeri 1 Taliwang Kabupaten Sumbawa Barat ini dapat menjadi contoh bagi pengikutnya, ketika mengawali setiap program yang dijalankannya. Perilaku Kepala Sekolah yang amat terpuji ini dapat memberikan pengaruh positif kepada semua tenaga kependidikan di dalam binaannya, untuk menerapkan implementasi programnya sehubungan dengan proses pembelajaran ataupun masalah-masalah yang berkaitan dengan sekolah secara keseluruhan. Sikap yang suka mendahului setiap kegiatan itu dapat mempengaruhi kinerja setiap pegawai yang ia pimpin untuk bekerja dengan giat. Hal ini sebagaimana pernyataan berikut: "Seorang pemimpin sekolah menurut saya baru bisa berhasil sekolah yang dipimpin itu, ketika ia memulai dari dirinya sendiri. Sehubungan dengan hal ini Kepala sekolah harus dapat mencerminkan sikap yang dapat diguguh dan ditiru oleh para pengikutnya. Segala sesuatu yang bersifat tingkah laku, atau perilakunya harus dapat menjadi panutan bagi orang-orang yang ia pimpin (W/KS1/040313/0830)".

Kepemipinan Kepala Sekolah ini peneliti melakukan pengambilan data melalui observasi. Kegiatan-kegiatan yang penulis observasi yaitu kegiatan yang berhubungan dengan penerapan kepemimpinannya sebagai leader.

Kepala Sekolah ini juga menjadi administrator yang andal dalam memberikan bantuan kepada bawahannnya. Menyangkut tugas kepemimpinannnya yang berhubungan dengan masalah-masalah administrasi ini, ia sangat kompeten dalam pengelolaannya. Hal ini peneliti mengumpul data juga melalui dokumentasi seputar tugas dan fungsi Kepala Sekolah sebagai leader.

Kepala Sekolah yang berwibawa dan disegani para bawahannya. Kepala sekolah yang mampu menampung mengakomodasi, atau menerima kritik-kritik dan saran-saran yang turut menyempurnakan kinerjanya. Kepala Sekolah juga mampu menyelesaikan komflik antar warga sekolah supaya selalu terjalinnya hubungan yang harmonis di kalangan stakeholders sekolahnya.

Kepemimpinan Kepala Sekolah Dasar Negeri 1 Taliwang ini relevan dengan pendapat Roobins (Husaini Usman, 2011) menyatakan bahwa esensi dari kepemimpinan adalah kejujuran.Niai-nilai inti dari pendapat ini meliputi nilai mutu, nilai kejujuran, nilai keterbukaan, dan nilai kepribadian.

Kedua teknik kepemimpinan ini sama-sama membahas dan menekankan mengenai adanya keterbukaan atau kejujuran seorang pemimpin. Selain itu penelitian di atas juga membahas selain jujur, juga pemimpin dapat membela yang benar atau bukan yang buyar.

Namun perbedaannya dengan penelitian ini adalah aspek kejujuran merupa- 
kan salah satu bagian yang diterapkan Kepala Sekolah.Aspek yang linnya misalnya aspek keprofesionalan, aspek ketegasan, aspek keuletan dan pantang menyerah, aspek kesopanan, rendah diri dan bermartabat, dan lain-lain juga sangat diperhatikan oleh Kepala Sekolah.

Upaya-Upaya Kepala Sekolah dalam menjalankan Visi, Misi, Tujuan, dan Sasaran Sekolah

Kepala sekolah SDN 1 Taliwang memiliki kompetensi dalam penyusunan program yang dapat mendukung tercapainya visi yang ditetapkan bersama itu. Penyusunan langkah-langkah strategis ini Kepala sekolah melibatkan dan memberdayakan seluruh stakeholders sekolah.

Upaya merealisasikan pencapaian hasil dan mendukung visi sekolah di atas, Kepala Sekolah sangat memperhatikan keseimbangan antara target pencapaian ilmu pengetahuan dan keterampilan dengan iman taqwa setiap siswa. Hal ini sesuai dengan pernyataan sebagai berikut: "Menurut saya apabila para siswa telah memiliki iman dan taqwa yang pantas, maka akan memberikan dukungan terhadap lancarnya rencana tiap-tiap guru dalam proses pembelajaran (W/KS1/040313/0803)".

Pengumpulan data sehubungan dengan hal ini peneliti juga memotret kegiatan yang berkaitan dengan pembinaan yang dilakukan Kepala Sekolah terhadap bawahannnya yaitu menekankan pelaksanaan pembelajaran PAIKEM. Pembelajaran Aktif, Inovatif, Kreatif, Efektif dan Menyenangkan (PAIKEM) sangat popular saat ini. Pola penerapan pembelajaran seperti itu, Kepala Sekolah ini selalu melakukan pembinaan kepada para guru agar dapat menerapkan pembelajrannnya supaya berjalan efektif.

Pengumpulan data juga dilakukan melalui dokumentasi tentang program Kepala Sekolah. Perencanaan dan penetapan visi, misi, tujuan, dan program yang melibatkan seluruh guru dan karyawan, siswa, orang tua (unsur komite) sekolah.
Pengusaan Kepala Sekolah dalam hal ini sesuai dengan pendapat Anderson (Husaini Usman, 2011) menyatakan bahwa pelaku pemimpin transformasional iala: visi, misi, perencanaan komunikasi dan tindakan kreatif yang memiliki efek positif sekelompok orang dalam sebuah susunan nilai dan keyakinan yang jelas, untuk mencapai tujuan yang telah ditetapkan dengan jelas dan dapat diukur.

Kedua penelitian ini nampaknya mengangkat hal yang sama seperti yang telah dinyatakan oleh Anderson di atas, walaupun ada beberapa perbedaannya seperti penerapan perilaku Kepala Sekolah untuk menegakkan disiplin warga sekolah tetapi mengenai kreativitas ini telah mencakup dalam pernyataan pendapat ahli di atas.

Bentuk Dukungan dari Followers dan Usaha-Usaha Pemberdayaan Guru

Para guru dan karyawan sekolah melakukan tugas dan fungsinya sesuai dengan harapan Kepala sekolah. Pada umumnya tenaga kependidikan dapat berperan sesuai dengan tupoksinya masingmasing.

Kepala sekolah mengajak atau menyarankan kepada bawahannya untuk memberikan dukungan moril maupun spiritual dalam rangkah meningkatkan semangat para bawahan untuk mengembangkan dirinya, sehingga nantinya dapat mengangkat nama baik dirinya secara khusus maupun mengangharumkan nama baik lembaga itu sendiri. Hal ini sebagaimana pernyataan berikut: "Kepala sekolah selalu memberikan dukungan secara moril seperti yang beliau pernah ucapkan, "Marilah kita berupaya memberikan yang terbaik di dalam kita melaksanakan pengabdian kita selaku guru atau karyawan sesuai dengan program yang kita jalankan. (W/GM3/030413/0810).

Mengenai pemberdayaan ini peneliti juga mengumpulkan data melalui observasi atau pemotretan kegiatan-kegiatan yang berhubunagn dengan pemberdayaan 
guru oleh Kepala Sekolah dalam kegiatan Imtaq.

Kepala Sekolah juga melakukan pemberdayaan kepada guru berupa diusulkannya 6 (enam) orang guru untuk mengikuti Pendidikan dan Pelatihan Calon Kepala sekolah, dan dinyatakan lulus dengan predikat memuaskan oleh LPMP (Lembaga Penjamin Mutu Pendidikan) Provinsi Nusa Tenggara Barat No. 1019/ J34/PP/2012 tanggal 12 November 2012 di Mataram.

Penelitian ini memiliki relevansi dengan penelitian "Kepemimpinan Kepala Sekolah dalam Pemberdayaan Guru". Penelitian ini bertujuan untuk memberikan pemberdayaan kepada guru dalam upaya melahirkan guru-guru yang kompeten. Persamaannnya menekankan masalah pemberdayan bawahan, Namun perbedaannya mengenai tempat dilaksanakannnya penelitian tersebut.

Bentuk-bentuk Apresiasi yang Dilakukan Kepala Sekolah

Kepala Sekolah sangat mengapresiasikan bawahannya dengan berusaha menstimulus para gurunya untuk berkreasi, dan berinovasi dalam memberikan pembinaan kepada siswa. Kepala Sekolah sangat menghargai hasil karya atau prestasi para bawahan atau siswanya. Kepala Sekolah selalu memberikan ucapan selamat kepada guru ataupun siswa atas prestasi yang telah diukir dari berbagai ajang kompetisi yang diikuti oleh sekolah.

Selain pemberian piagam penghargaan dan hadiah seadanya kepada setiap yang berhasil mengangkat nama baik sekolah itu, Kepala sekolah juga menyatakan bahwa siapa saja yang berhasil mengharumkan nama sekolah, maka sesekali kita akan melaksanakan studi pembelajaran ke sekolah-sekolah terbaik di Indoneia. Bukan hanya ke sekolah-sekolah terbaik saja akan kita kunjungi, melainkan kita juga akan memperluas wawasan kita termasuk ke daerah-daerah atau kota-kota terbaik di Indonesia. Hal ini sebagaimana pernyataan berikut: "Di samping itu kami memprog- ramkan kegiatan yang dapat memotivasi kinerjanya dan dapat memperluas pengalaman mereka, seperti kegiatan studi banding atau tour pembelajaran ke sekolah-sekolah atau kota-kota terbaik yang ada di Indonesia. (W/KS3/040413/0830).

Kepemimpinan Kepala Sekolah ini dapat melakukan pengarsifan hasil-hasil yang dicapai para guru ataupun siswanya dengan rapih. Keberhasilan siswa dari berbagai kompetisi ysng ditemui penulis banyak mendapat sertifikat kejuaraan. Dalam hal ini penulis berhasil mengumpulkan beberapa sertifikat-sertifikat kejuaraan yang diperoleh siswa.

Kepemimpinan Kepala Sekolah Dasar Negeri 1 Taliwang ini memiliki kesamaan dengan satu penelitian yang relevan dengan penelitian ini taitu "Effectiveness leadership qualities and characteristics of urban shool principals". Perbedannya yaitu tempat penelitiannya. Penelitian ini di tingkat sekolah dasar, namun penelitian tersebut dilaksanakan di sekolah menengah.

Bntuk Kegiatan Menciptakan Situasi Sekolah yang Kondusif

Situasi sekolah yang jauh dari gangguan akan memberikan ketenanagan bagi peserta didik untuk belajar dengan lebih hidmat, menyenangkan, dan lebih bermakna semua konsep materi pelajaran yang dipelajarinya. Kekondusifan situasi sekolah itu dapat diciptakan sedemikian rupa oleh Kepala sekolah. Dalam mengkondisikan lingkungan sekolah yang nyaman dan kondusif ini menjadi salah satu variabel yang harus diperhatikannya, sehingga program-program yang telah diprogramkan itu dapat tercapai secara maksimal.

Upaya pembentukan situasi sekolah yang kondusif ini, sungguh menjadi program yang dapat disusun dengan terencana oleh Kepala Sekolah ini. Usahausaha untuk menciptakan situasi yang kondusif ini sangat diperhatikan oleh Kepala SDN 1 Taliwang ini.

Menyangkut masalah ini hampir sama maksud dan pandangannnya dengan pendapat Stolp \& Smith (1995: 16) me- 
nyatakan behwa pembentukan lingkungan yang beriklim kondusif untuk mendukung seluruh program perencanaan sekolah oleh Kepala Sekolah merupakan hal yang mutlak.

Perbedaannya dengan konsep penelitian ini yaitu penelitian ini memfokuskan atau menkhususkan tentang pembentukan situasi sekolah yang kondusif yang dilakukan oleh Kepala Seakolah dalam upaya mendukung pencapaian tujuan pembelajaran secara maksimal.

\section{Hal-Hal Positif oleh Kepala Sekolah}

Keakraban pihak sekolah dengan sekolah dapat menjadi salah satu modal bagi sekolah untuk memudahkan penerapan program-program yang telah tersusun. Bagaimana pun juga dukungan masyarakat sangat diperlukan oleh setiap Kepala sekolah dalam memimpin suatu sekolah. Keharmonisan sekolah dengan masyarakat setempat ini dibenarkan oleh Bapak Zh selaku security sekolah di sekolah ini dengan menyatakan: "Menurut pendapat saya, karena sekolah ini dekat dengan rumah penduduk, selalu terjalin komunikasi yang santun antara pihak sekolah dengan masyarakat (W/SeZ2/020413/0830)".

Hal-hal positif yang berhasil peneliti observasikan misalnya pelaksanaan kegiatan Imtaq. Kepala Sekolah sangat menegakkan kegiatan pembinaan siswa melalui kegiatan Imtaq. Kegiatan Imtaq ini Kepala Sekolah menyerahkan sepenuhnya kepada guru agama untuk merencanakannya, mengaturnya dan pelaksanaannya. Kegiatan Imtaq ini diadakan setiap hari Jum'at setiap bulannya.Wadah yang bagus ini dapat dilaksanakan oleh para guru dan siswa sebagai pemeran utamanya.

Penelitian yang relevan dengan halhal ini yaitu "Peran Kepemimpinan Dalam Pengembangan Budaya di Sekolah". Kedua penelitain ini sama-sama menitikberatkan tentang upaya terjalinnya hubungan yang harmonis di kalangan seluruh tenaga kependidikan di sekolah.

Namun, perbedaannya dengan penelitian ini adalah penelitian tersebut ditulis oleh Yeremias Ganggur Bero (2008), tempat penelitiannnya yaitu SMP Katolik Pengdi Luhur 1 dan SMP Kotolik Pengudi Luhur 2 Yogyakarta, sedangkan penelitian ini dilaksanakan di sekolah dasar.

\section{Simpulan dan Saran}

Berdasarkan hasil penelitian dan pembahasan mengenai kepemimpinan Kepala Sekolah Negeri 1 Taliwang Kabupaten Sumbawa Barat, dalam hal ini penulis dapat menyimpulkan antara lain.

Kepala sekolah sebagai leader

Simpulan yang berhubungan dengan fungsi Kepala Sekolah sebagai leader ini meliputi: "Kepala SDN 1 Taliwang dapat menerapkan kepemimpinannya dengan memberikan keteladanan yang tepat untuk membentuk/menciptakan sekolahnya menjadi sekolah yang bermutu; Keteladanannya ditunjukkan melalui penerapan semua program yang dijalankan sehingga setiap bawahannya dapat menyikapi dengan sungguh-sungguh untuk menyukseskan tiap program yang dilakukan; Kepala Sekolah dapat menggunakan seluruh aspek kompetensinya untuk memaksimalkan fungsinya, dan setiap bawahannya dalam rangka mencapai tujuan secara optimal.

Upaya Kepala Sekolah dalam menjalankan visi, misi, tujuan dan sasaran sekolah

Berkaitan dengan hal ini, Kepala SDN 1 Taliwang mengoptimalkan kompetensinya sebagai administrator sekolah dengan maksimal. Kepala Sekolah melakukan penyusunan perencanaan sekolah yang teratur, sistimatis, dan lengkap dalam pengelolaan sekolah. Kepala Sekolah menerapkan kegiatan Imtaq, sebagai salah satu bentuk kegiatan yang dapat mendukung pencapaian visi, misi sekolah.

Bentuk-bentuk Dukungan Followers dan Upaya-Upaya Pemberdayaan Guru oleh Kepala Sekolah

Bentuk-bentuk dukungan dari followers ditunjukkan berupa kesungguhannya 
dalam penerapan program pembelajaran ataupun program sekolah. Hasil yang dicapai para siswa dalam bidang akademik maupun kegiatan ekstra kurikuler selalu berhasil dengan sangat signifikan dan dapat memuaskan semua pihak. Kepala Sekolah telah melakukan pengkaderan beberapa bawahannya untuk diusulkan sebagai calon Kepala Sekolah.

Bentuk-Bentuk Apresiasi yang Dilakukan Kepala Sekolah

Pemberian apresiasi yang dilakukan Kepala Sekolah berupa apresiasi berhubungan dengan administrasi dan melakukan kegiatan yang bersifat dapat memotivasi siswa dan guru untuk meningkatkan kualitasnya.

Kepala sekolah tetap menggunakan kata-kata yang santun, dan nyaman didengar. Setiap orang yang berkomunikasi dengan beliau selalu memperoleh kepuasan tersendiri karena penerimaan dan penyambutan beliau yang sangat menghargai siapa saja yang berkepentingan dengannya. Para guru di sekolah selalu merasa terlayani dan dihormati oleh bapak Kepala sekolah. Perilaku Kepala sekolah seperti ini membuat para guru dan karyawan bersemangat melakukan tugasnya sesuai dengan tupoksinya masing-masing. Hal ini sebagaimana pernyataan berikut: "Menurut pengamatan saya, Kepala Sekolah dalam menciptakan ikim sekolah yang kondusif ini beliau mengembangkan hubungan rasa solidaritas, rasa kebersamaan, dan rasa kekeluargaan yang harmonis. Penerapan nuansa seperti ini amat tepat dalam membentuk iklim sekolah yang kaya dengan nilai-nilai positif yanga amat berguna dan mendukung keberhasilan program kegiatan yang sedang dan akan dilaksanakan oleh para guru. (W/GN1/ 050313/0820)".

Pembentukan Situasi Sekolah yang Kondusif

Upaya pembentukan situasi yang kondusif ini Kepala Sekolah melakukan dengan menerapkan dan membiasakan warga sekolahnya untuk menjaga kesopanan, dan santun dalam berbicara. Di samping itu Kepala Sekolah sangat memperhatikan keamanan sekolah baik dalam proses pembelajaran maupun di luar aktivitas proses pendidikan.

Hal-Hal Positif yang Dilakukan Kepala Sekolah

Adapun hal-hal positif yang diakukan Kepala SDN 1 Taliwang Kabupaten Sumbawa Barat antara lain: "Sekolah ini menggiatkan pelaksanaan kegiatan Imtaq untuk membentuk siswa yang berkepribadian yang bermartabat; Kepala Sekolah dapat membiasakan warga sekolahnya untuk menjaga hubungan yang harmonis dalam kesehariannnya; Pembiasaan siswa yang siap bersaing dalam berbagai perlombaan baik dalam bidang akaedemik maupun kegiatan pengembangan bakat; Kepala Sekolah dapat menjaga dan melestarikan hubungan yang harmonis dengan masyarakat di sekitarnya".

\section{Saran-Saran}

Berdasarkan proses pengambilan data dalam penelitian ini, Sekolah Dasar Negeri 1 Taliwang Kabupaten Sumbawa Barat yang dijadikan tempat setting penelitiannya, maka Peneliti dapat memberikan beberapa saran sebagai berikut:

1. Diharapkan kepada Kepala SDN 1 Taliwang harus dapat meningkatkan dan mempertahankan teknik kepemimpinan yang dijalankan, sebab pola kepemimpinan yang diterapkan itu dapat menghasilaknan hasil signifikan. Kepala sekolah memanfaatkan sumber daya yang dimiliki sekolah ini dengan lebih berdayaguna dan berhasilguna. Kepala sekolah juga harus dapat mengamankan seluruh asset sekolah dengan aman dan terkendali. Kepala sekolah mempertahankan cara-cara pembentukan iklim sekolah yang kondusif itu, sebab situasi ini menjadi salah satu bagian terpenting untuk menghasilakn hasil yang efektif, 
2. Diharapkan kepada Kepala sekolah harus dapat berkoordinasi dengan harmonis dengan pihak dinas pendidikan mulai dari pihak Unit Pelaksana Teknis Dinas di tingkat kecamatan dan sampai pada jajaran dinas di atasnya. Kepala sekolah memaksimalkan hubungannya untuk mengakses seluruh informasi yang berkenaan dengan pendidikan yang akan dijalankannya. Unit Pelaksana Teknis Dinas kecamatan supaya memberi pelayanan yang cukup kepala Kepala sekolah dalam upaya keberhasilan menciptakan sekolah yang bermutu.

3. Di samping itu pula Kepala sekolah agar melakukan komunikasi intens dengan pihak Pemerintah melalui Dinas Pendidikan dan Kebudayaan Kabupaten Sumbawa Barat, dalam rangka upaya mengefektifkan seluruh program sekolah untuk mendukung terciptanya visi dan misi sekolah yang telah ditetapkan secara bersama-sama tersebut.

\section{Daftar Pustaka}

Andriani, D.E. \& MM. Wahyuningrum. (2011). Penguasaan kompetensi manajerial kepala Sekolah Dasar (SD) dalam Implementasi Manajemen Berbasis Sekolah. Yogyakarta: FIP UNY.

Cunningham, W.G \& Cordeiro, P.A. (2009). Educational leadership. Boston: Pearson.

Crawford, E \& Brooke. (2013). Four key factors of effective school leadership. Diambil pada tanggal 6 Juni 2013, http:// search.proquest.com/docvie $\mathrm{w} / 305172780 / 1380 \mathrm{D} 34 \mathrm{~A} 4555 \mathrm{~B} 14 \mathrm{~F} 6$ A8/270?accountid=31324.

Danim, Sudarwan. (2010). Kepemimpinan pendidikan. Bandung: Alfabeta.

Danim, Sudarwan \& Suparno. (2009). Manajemen dan kepemimpinan transformasional kekepalahsekolahan. Jakarta: PT Rineka Cipta.
Euis Karwati \& Donni Juni Priansa.(2013). Kinerja dan profesionalisme kepala sekolah. Bandung: Alfabeta.

McMillan, J H. (2013). Educational reaserch fundamentals for the costumer. Virginia: Pearson.

Milles, M. B. \& Huberman, A. M. (1994). Qualitative data analysis. California: Sage.

Prasojo, L.D. \& Sudiyono.(2011). Supervisi pendidikan. Yogyakarta: Gaya Media Indonesia.

Ramdhani, Neila. (2012). Menjadi guru inspiratif. Jakarta: Titian Foundation Indonesia.

Sallis, E. (2011). Manajemen mutu terpadu pendidikan. Yogyakarta: IRCiSoD.

Sorenson, R.D.\& Goldsmith, L.M. (2009). The principal'sguideto managingschool personnel. California: Corwin Press.

Stolp, S \& Smith, S.C. (1995). Transforming school culture. Machigan: University of Oregon.

Ulfah Umurohmi. (2007). Kepemimpinan kepala sekolah dalam pemberdayaan guru di Madrasah Mualimat Muhammadiyah Yogyakarta. Tesis magister tidak diterbitkan, Universitas Negeri Yogyakarta, Yogyakarta.

Usman, H. (2011). Manajemen "Teori, praktik, dan riset pendidikan". Jakarta: PT Bumi Aksara.

Wahjosumidjo.(2011). Kepemimpinan kepala sekolah. Jakarta: PT Rajagrafindo Persada.

Wuradji. (2009).The educational leadership. Yogyakarta: PT Gama Media.

Yukl.G. (2010).Leadership in organizations. New Jersey: PearsonPrentice Hall.

Zuchdi, D. (2011). Pendidikan karakter dakam perspektif teori dan praktik. Yogyakarta: UNY Pres. 